International Journal of Instruction e-ISSN: 1308-1470 • www.e-iji.net

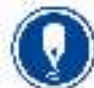

Article submission code: 20191210080518
Received: 10/12/2019

Revision: 21/12/2020
July $2021 \bullet$ Vol.14, No.3

p-ISSN: 1694-609X

pp. 375-392

Accepted: 15/01/2021

OnlineFirst: 22/05/2021

\title{
Mathematics and Cultures: A New Concept in Maintaining Cultures through the Development of Learning Devices
}

\section{Sri Rezeki}

Mathematics Department, Universitas Islam Riau, Indonesia, sri_rezeki@edu.uir.ac.id

\section{Dedek Andrian}

Dr., corresponding autor, Mathematics Department, Universitas Islam Riau, Indonesia, dedekandrian@edu.uir.ac.id

\section{Yulia Safitri}

Mathematics Department, Universitas Islam Riau, Indonesia, yulisafitri647@gmail.com

$$
\begin{aligned}
& \text { The game is a very close and inseparable part of the child's life. Games will be } \\
& \text { effective media in maintaining culture through learning. This study aims to develop } \\
& \text { a learning tool in the form of a Student Activity Sheet (SAS) and a learning } \\
& \text { implementation plan (LIP) that can connect between culture and mathematics } \\
& \text { through the Realistic Mathematics Education (RME) approach. Regional } \\
& \text { traditional games used in this study were Static, Long Galah, Guli and Congkak } \\
& \text { games. Static, Long Galah,, Guli, and Congkak games was selected through studies } \\
& \text { on the adaptation of Malay culture to mathematics and expert Focus Group } \\
& \text { Discussion (FGD). The development of SAS learning in this study uses a Plomp } \\
& \text { modification consisting of several phases, namely: (1) initial investigation; (2) } \\
& \text { design; (3) construction; (4) tests, evaluations, and revisions. The product trial was } \\
& \text { carried out in the Mandau district elementary school. The instrument used in this } \\
& \text { study was the LIP and SAS validation sheets used by experts, practitioners, and } \\
& \text { students to assess LIP and SAS. Data analysis in this study used descriptive } \\
& \text { statistics by comparing the validation and practical criteria of a learning tool. From } \\
& \text { the research results obtained the results of the validity test LIP Statac Games, } \\
& \text { Galah Panjang, Guli and Congkak with an average of each game; } 76.61 \%, 82.76 \text {, } \\
& 83.39 \text {, and } 84.40 \text {, with the criteria quite valid while SAS obtained the average } \\
& \text { value of each permanent namely; } 77,88.2,81.5 \text { and } 84.1 \text {. From the questionnaire } \\
& \text { given to students after SAS was implemented, an average score of } 9 \text { was obtained } \\
& \text { with a very practical category. the results of this study indicate that this } \\
& \text { development research has produced a learning tool based on Malay folk Malay } \\
& \text { Riau game with a valid and practical. }
\end{aligned}
$$

Keywords: development, learning device, malay traditional game, mathematics, cultures, learning devices

Citation: Rezeki, S., Andrian, D., \& Safitri, Y. (2021). Mathematics and Cultures: A New Concept in Maintaining Cultures through the Development of Learning Devices. International Journal of Instruction, 14(3), 375-392. https://doi.org/10.29333/iji.2021.14322a 


\section{INTRODUCTION}

Technology development at era industry revolution 4.0 enables everyone to adapt to the new technology that has been created. The impact of the current technological advancement makes the student lose from culture and don't know about the culture their region had. Impact of development makes students don't care about their homework, schools' task, health, social environment (Raut \& Patil, 2016). students who use technology excessively will have a negative impact on the learning process in the classroom where students cannot think well about their lessons (Olaore, 2014). This era makes students focus on android or gadget, active in using social media, playing the game any time and forget about homework or school tasks. Student enjoys with online activities without giving attention to schools. When the teacher asks the student to answer one thing about culture, only $10 \%$ of students can answer correctly. Next experiment is given by the teacher about the culture thing, the teacher still got the same answer from students where only $12 \%$ of students can answer correctly teacher question about culture. This problem to be something need a serious solution for solving this problem because this problem will affect the learning process and the student learning outcome.

Riau is one of the provinces in Indonesia which is famous as a Malay country that have a lot of customs and cultures such as; folklore, regional game, weaving traditional cloth, traditional music, and regional cuisine. However, at this time Malay culture slowly disappeared by foreign culture and shifted the local culture. This was revealed by Bungsu (2015) that "Riau is currently experiencing a lot of changes and shifts in cultural values within the community due to the advancement of science and technology, which subsequently provides opportunities for the neglect of Malay culture and customs". Andrian, Kartowagiran, and Hadi (2018) say that is needed a strategy or way to maintain cultures and customs because the advancement of science and technology make the young generation or student neglect cultures and customs have been had by region. In developing Malay culture, the world education sector is also included by involving cultural elements in school subjects. However, so far only art subjects have involved elements of culture in the learning process.

Based on the results of interviews with the teachers and classroom observations there were found problems regarding the learning process, that is; In the learning process, Malay cultures haven't yet maximally known to student in the classroom, the Malay cultures in form figure, pattern, sketch, picture haven't utilize by schools for implemented in classroom yet. The teacher ability in developing the learning device was still low, the teacher uses LIP and SAS have obtained from the internet and is used without repairs/revisions, learning activities were still teacher-centered. In addition, there is no time allocation at each stage of the activity. The teacher did not use SAS as one of the teaching materials. The teacher only conveyed the material and wrote the questions on the board then asked some students to complete it in front of the class. Students are less interested in learning because students become passive and only listen to the teacher more than doing activities in the classroom. Related to the material taught, the teacher also admitted that they rarely associated it with the real-life of students, 
materials haven't arranged in the form of stories yet, the game especially related to Riau Malay culture. In fact, the elementary school students are still at a concrete stage that requires real objects or something close to their environment so that learning for them can run optimally.

Based on the explanation above, the development of learning tools in the form of LIP and SAS mathematics by linking cultural elements in the form of Riau Malay traditional games to elementary school children. In this case trying to manipulate the abstractness of the object of mathematics learning towards more concrete by using RME where RME is an approach that directs the contextual learning problem or concrete and logical problem. People's games were chosen because according to the characteristics of elementary school-age children are still happy to play. Folk games combined with mathematics learning are expected to be an effective means of transferring knowledge about culture and student learning outcomes. Traditional games is a form of concrete objects can increase students' understanding of culture and mathematics itself. Therefore, product development in the form of LIP and SAS through Piaget learning theory with RME based on the Malay traditional games of Riau can achieve meaningful learning goals for students and preserve Riau's Malay culture.

\section{Literature Review}

Mathematics is a living subject which seeks to understand patterns that permeate both the world around us and the mind within us (Schoenfeld, 1992). Mathematics learning is process how to give understand at student about mathematics subject with constructing knowledge (Freeman et al., 2014). Mathematics learning is activity of determining cognitive functioning underlying the diversity of mathematics processes (Duval, 2006). Mathematics learning is a effort to support how mathematics achievement of student in classroom can be reached (Bergeson, 2000).

Mathematics learning is the serious problem must be solved by teachers, researchers, practitioners because this problem has given an effect on students' achievement (Vinner, 2015). The research about improve mathematics learning is very important to be noticed by the researchers because they will get specific problem about learning and teaching of mathematics (Lerman, 2014). Learning and teaching in mathematics are part of effort how to make mathematics learning can be fun with specific tool or strategy (Gutstein \& Chicago, 2003). The mathematics learning can be improved by some of pedagogical practices that may help learners develop mathematical understanding(Schleppegrell, 2014). One of way how to improving mathematics learning is by developing the mathematics language because development of the language of mathematics is an essential aspect of teaching mathematics to young children (Riccomini, Smith, Hughes, $\&$ Fries, 2015).

Improving the mathematics learning can be done by developing curriculum materials, frameworks, success standard, assessment, professional development and evaluation (Hill, Ball, Hill, \& Loewenberg, 2004).The strength of relationships of mathematics teaching and learning can increase the mathematics outcome by determining conceptual framework that links the instructional task with the learning result (Stein \& Lane, 1996). 
The concept understand is basic task must be explained by teacher because the concept understand is very important in affecting teaching and learning result in classroom (Alibali, Nathan, \& Nathan, 2012).

Many things can be done to improve the mathematics learning and teaching. The research mathematics education has tried and explained how to improve the mathematics teaching and learning (Artigue, 1999). Teachers can motivate students by the motivation videos as a pre-service before learning in the classroom was begun (Star \& Strickland, 2008). Teacher must learn to teach in many ways such as developing higher-order thinking and performance, trying new strategy that can increase the learning outcomes (Darling-hammond \& Richardson, 2009). Improving the teaching and learning quality can be done by building a relationship between teachers and student so that the teacher directly can evaluate weakness and students difficulties in learning mathematics (Kersting, Givvin, Angeles, Stigler, \& Angeles, 2010).

Learning mathematics used culture is a effort how to balance between culture and education (Wood \& Ashfield, 2008). Teaching and Learning activities can be an effective and interesting for student because learners to be more in love with the characteristics and culture of the region (Prastiwi, 2013). Introducing culture of region through education can be affective to transform the value of kindness to students(Strouse \& Nickerson, 2016). Students can design knowledge with adapting to the surrounding culture (Durmuş, 2016). Balancing of both culture and learning can give effective result because there are two things which run simultaneously and can be developed maximally (Andrian, Kartowagiran, \& Hadi, 2018). Learning activities that are followed by cultures activities can be maximally in improving and developing learning and even culture from a region because the using tools from region culture can provide benefits for both region culture and learning automatically (Hadi \& Andrian, 2018; Shih, Velan, \& Shulruf, 2017). The teacher education is important role in ensuring quality of teaching and learning in classroom (Akyeampong, Lussier, Pryor, \&Westbrook, 2015). Learning media has developed by can bridge learning with culture(Greenhow \& Lewin, 2016).

RME one of method emphasizes at context problem which are intended for supporting the teaching and learning process. This method enables student to overcome the mathematics formal (Gravemeijer \&Doorman, 1999). RME are used to elicit the student understanding about mathematics in real context (Panhuizen, 2003). Concept of RME is "realistic situation". This situation enables educators develop the learning tools, and procedures as a context which student can solve problems are found in field directly (Heuvel-Panhuizen\&Drijvers, 2014). RME emphasized the learning mathematics in realistic situation, in this context, student do an invention or construct a solution procedure to solve problem (Kwon, 2002). RME is involved student has active role in observing the real situation objects being studied because Mathematics is a human activity that involves observing, representing and investigating object or pattern (Barnes,2005). 


\section{METHOD}

This research is development research. Borg and Gall (1983) states that development research is a method used to develop educational product and test product effectiveness. Research design used in this research was proposed by Plomp(Akker, Bannan, Kelly, Nieveen, \& Plomp, 2007) consists of; (1) initial investigation phase, (2) design phase, (3) realization phase, (4) trial, evaluation, and revision, (5) implementation phase.

\section{Sample \&Sampling Technique}

The sample used in this research was students and teachers of Elementary School of Mandau District of Riau Province. The reason elementary school as participant this research because elementary school was lowest level from formal education which give knowledge about culture in every district of Indonesia. Students with relatively young age was expected to have aspirations in developing regional uniqueness by integrating it with education such as mathematics education.The sampling technique used in this research was purposive sampling. The reason way used purposive sampling is because it can select the samples properly according to purpose of the research will be done(Eğmir, Erdem, \& Koçyiğit, 2017).

\section{Instrument}

Instruments for collecting data consist of, validation sheet of LIP, validation sheet of SAS, practicality questionnaire of LIP was filled by teachers, practicality questionnaire of LIP was filled by students, practicality questionnaire of SAS was filled by teachers, practicality questionnaire of SAS was filled by students and the questionnaire to measure implementation of product was development by researcher. The validation sheet of LIP is used to assess whether the LIP has developed by researcher is valid. The SAS validation sheet is used to judge whether the learning device in form SAS is valid category. Practicality questionnaire of LIP and SAS are used to judge or assess whether the questionnaires is practical category. Validation sheet of LIP and SAS are filled out by experts and practitioners, while practicality questionnaires of LIP and SAS are filled out by experts, practitioners, and students.

\section{Data Analysis Techniques}

Data analysis techniques in this research were used formula for analyzing validity and formula for analyzing practicality of product proposed by Akbar (2013). The formulas were proposed by Akbar can be seen at Formula 1 and 2 .

\section{Formula for analyzing of Validity}

$$
V=\frac{V a_{1}+V a_{2}+V a_{3}+V a_{4}}{4}=\%
$$

Note:

$V \quad=$ Combined Validity

$V a_{1}=$ Validity from first expert

$V a_{2} \quad=$ Validity from second expert

$V a_{3}=$ Validity from third expert

$V a_{4} \quad=$ Validity from fourth expert 
Formula for analyzing of practicality level

$$
P=\frac{T S e}{T S h} \times 100 \%
$$

Note:

$P \quad=$ Percentage of practicality

TSe $=$ Total of Score

TSh = Maximal Score Total was Expected

Validity Criteria for Product has Developed

Table 1

The validity and practicality criteria

\begin{tabular}{|c|c|c|}
\hline Range o & Level of Validity & Level of Practicality \\
\hline $85,01 \%-100 \%$ & Very valid & Very Practical \\
\hline $70,01 \%-85 \%$ & Enough valid & Enough Practical \\
\hline $50,01 \%-70 \%$ & Less valid & Less Practical \\
\hline $01,00 \%-50 \%$ & Not valid & Not Practical \\
\hline
\end{tabular}

\section{FINDINGS}

\section{Initial Investigation}

Initial investigations were conducted by interviewing public elementary school teachers in Mandau. Based on the results of the interviews found several problems experienced by the teacher in teaching and learning activities. The teacher had difficulty making the proposed learning tools in the 2013 curriculum. Another problem that occurred at the school was that the teacher had never made a Student Activity Sheet (SAS) that he designed himself. SAS used is still general in nature and does not associate with Riau Malay folk games into mathematics learning. The main factor that makes teachers unable to develop SAS is not having time because of a large teaching load.

In addition to interviews with teachers, researchers also conducted interviews with a number of elementary school students. From the interviews, information was obtained that students did not know much about the various kinds of folk games in Riau. This is because advances in increasingly sophisticated technology make students only play at home using smartphones so that folk games are increasingly lost and almost unknown to children today.

For reinforcing initial investigation, FGD were conducted by attending experts to discuss about SAS and LIP that integrated with Malay Culture. FGD was conducted to get the assessment and suggestion from expert about the SAS and LIP that integrated with Malay culture. There were nine expert have given the assessment and suggestion about SAS and LIP that have developed. The experts gave the assessment and suggestion about Malay culture object will be used. According expert the Malay culture object was Regional traditional game namely; Static, Long Galah, Guli and Congkak games. Static, Long Galah,, Guli, and Congkak can be integrated will mathematics 
material at elementary schools. the expert said that these game will be interesting and can be effective way to know malay culture to students elementary schools where the students age of elementary school is productive age for transferring the knowledge about culture and even everything knowledge. Expert gave suggestion about SAS the design. SAS design was important thing must be paid attention because the students age of elementary schools very happy with something interesting so the colour of SAS, font of SAS, th use of picture in the SAS must be arranged correctly and carefully. Test for measuring the understanding students on the SAS must be made carefully. In this context, kind of test will be used for detecting the students ability after studying SAS must be appropriate with the material in the SAS. There were three aspects in the SAS must be shown were instruction in using the SAS, brief material but clear and easy to understand, and test that represent the material have developed in the SAS.

\section{Design}

\section{Design LIP}

At this stage, the learning tools and research instruments that are needed are based on studies conducted at the initial investigation stage. In this design phase, an LIP and SAS picture is obtained which is developed. LIP is a guide to the steps to be taken by the teacher in learning that is arranged in the activity scenario. The preparation of the LIP is focused on training students' skills to work together in solving a problem based on the traditional Malay traditional game of Riau.

\section{Design SAS}

The development of SAS aims to check the students 'level of understanding of the material that has been presented and train students' skills in working together to solve contextual problems through the Riau-based Malay culture-based SAS in the form of traditional Malay traditional games of Riau. After carrying out a needs analysis, researchers conducted data collection needed in the development of LIP and teaching materials in the form of SAS 2013 curriculum.

\section{Realization or Construction}

his realization is carried out by determining elementary mathematics competencies that will be used as a foundation in the development of learning materials that will be included in the LIP, identifying PMR steps that will serve as guidelines for learning, and identifying Riau Malay traditional games presented in SAS. The results of this realization are mathematical learning tools by using a realistic mathematical approach (PMR) consisting of LIP and SAS based on the Malay traditional games known as Prototype 1.

\section{Trial, Evaluation and Revision}

\section{Validation of LIP}

Validation activities in learning mathematics using PMR. Prototype 1 is consulted to the validator and then validated by the validator. Based on the results of the validation, a 
revised prototype was validated to obtain prototype 2 which was then used for field trials. LIP validation was carried out by evaluation experts, instruments, mathematics learning and practitioners. Results can be seen in Table 2.

Table 2

Results of the LIP validated for statak game

\begin{tabular}{|c|c|c|c|c|c|c|c|c|c|c|}
\hline \multirow[t]{2}{*}{ The Validated Aspect } & \multicolumn{4}{|c|}{$\begin{array}{l}\text { Expert Assessment of } \\
\text { LIP for } 4 \text { Meeting }(\%)\end{array}$} & \multicolumn{4}{|c|}{$\begin{array}{l}\text { Practitioners Assessment } \\
\text { of LIP for } 4 \text { Meeting (\%) }\end{array}$} & \multirow{2}{*}{$\begin{array}{c}\text { Mean } \\
(\%)\end{array}$} & \multirow[t]{2}{*}{ Criteria } \\
\hline & 1 & 2 & 3 & 4 & 1 & 2 & 3 & 4 & & \\
\hline $\begin{array}{l}\text { Learning Objective } \\
\text { Formulation }\end{array}$ & 72 & 83.5 & 83 & 82 & 77.1 & 77.1 & 79.2 & 79.2 & 79.14 & Enough \\
\hline Learning Material & 78 & 78 & 76.5 & 75 & 75 & 66.7 & 66.7 & 75 & 73.86 & Enough \\
\hline Learning activities & 84.5 & 79 & 81 & 82.5 & 76.7 & 76.7 & 78.3 & 76.7 & 79.43 & Enough \\
\hline Learning source & 80 & 77 & 77.5 & 79.5 & 79.2 & 79.2 & 79.2 & 75 & 78.33 & Enough \\
\hline Assessment Instrument & 71.5 & 78 & 84.5 & 77.5 & 66.7 & 66.7 & 66.7 & 66.7 & 72.29 & Enough \\
\hline Mean & & & & & & & & & 76.61 & Enough \\
\hline
\end{tabular}

Based on Table 3, acquired the average of learning objective formulation was $79.14 \%$ with enough category. The aspect of learning activities was acquired the average was 73.86 with the enough category. The aspect of learning sources was acquired the average was 78.39 with the enough category. The aspect of assessment instrument was acquired the average 72.29 with enough category. This result showed that according to the expert and practitioners LIP can be used in the learning and teaching process with some revision. Experts and practitioners said that the LIP can be effectiveness tools to combine mathematics material with Riau Province cultures.

Table 3

$\underline{\text { Results of the LIP validated for galahpanjang game }}$

\begin{tabular}{|c|c|c|c|c|c|c|c|c|c|c|}
\hline \multirow[t]{2}{*}{ The Validated Aspect } & \multicolumn{4}{|c|}{$\begin{array}{l}\text { Expert Assessment of } \\
\text { LIP for } 4 \text { Meeting (\%) }\end{array}$} & \multicolumn{4}{|c|}{$\begin{array}{l}\text { Practitioners Assessment } \\
\text { of LIP for } 4 \text { Meeting }(\%)\end{array}$} & \multirow{2}{*}{$\begin{array}{c}\text { Mean } \\
(\%)\end{array}$} & \multirow[t]{2}{*}{ Criteria } \\
\hline & 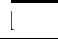 & $?$ & 3 & $t$ & l & 2 & 3 & $t$ & & \\
\hline $\begin{array}{l}\text { Learning Objective } \\
\text { Formulation }\end{array}$ & 79.5 & 35.5 & 37.5 & 34.0 & 36.0 & 31.5 & 36.0 & 77.5 & 83.44 & Enough \\
\hline Learning Material & 79.0 & 35.0 & 36.0 & 78.0 & 78.0 & 39.0 & 36.5 & 78.0 & 82.44 & Enough \\
\hline Learning activity & 79.0 & 31.5 & 34.5 & 34.5 & 78.0 & 35.0 & 34.5 & 32.0 & 82.38 & Enough \\
\hline Learning source & 31.0 & 37.5 & 36.0 & 34.5 & 72.0 & 35.5 & 30.5 & 34.0 & 82.63 & Enough \\
\hline Assessment Instrument & 73.0 & 35.5 & 37.0 & 33.5 & 77.5 & 38.0 & 35.5 & 33.5 & 82.94 & Enough \\
\hline Mean & & & & & & & & & 82.76 & Enough \\
\hline
\end{tabular}

Table 3 showed the results of LIP validated by experts and practitioners for Galah Panjang Game. The learning objective formulation aspect was acquired the average 83.44 with enough category. The learning material aspect was acquired the average 82.44 with enough category. The learning activities were acquired the average 82.38 with enough category. The learning sources were acquired the average 82.63 with enough category. The assessment instrument was acquired the average 82.94 with enough category. From five aspects that have assessed by experts and practitioners can 
be concluded that the GalahPanjang Game combined the mathematics materials was valid and appropriate used in the teaching and learning processes.

Table 4

Results of the LIP validated for guli game

\begin{tabular}{lccccccccccc}
\hline \multirow{2}{*}{ The Validated Aspect } & \multicolumn{3}{c}{$\begin{array}{l}\text { Experts Assessment of } \\
\text { LIP for 4 Meeting (\%) }\end{array}$} & \multicolumn{4}{c}{$\begin{array}{c}\text { Practitioners Assessment } \\
\text { of LIP for 4 Meeting (\%) }\end{array}$} & \multirow{2}{*}{$\begin{array}{c}\text { Mean } \\
(\%)\end{array}$} & Criteria \\
\cline { 2 - 9 } & 1 & 2 & 3 & 4 & 1 & 2 & 3 & 4 & \\
\hline $\begin{array}{l}\text { Learning Objective } \\
\text { Formulation }\end{array}$ & 92.5 & 85.5 & 83.5 & 78.0 & 77.5 & 88.0 & 86.5 & 81.0 & 84.06 & Enough \\
\hline Learning Material & 87 & 85.0 & 86.5 & 77.0 & 75.5 & 84.0 & 86.0 & 74.0 & 81.88 & Enough \\
\hline Learning activity & 84 & 81.5 & 81.0 & 83.0 & 79.0 & 85.0 & 85.5 & 83.0 & 82.75 & Enough \\
\hline Learning source & 89.5 & 87.5 & 80.0 & 82.5 & 80.5 & 84.0 & 85.0 & 84.5 & 84.19 & Enough \\
\hline Assessment Instrument & 87 & 85.5 & 87.0 & 81.0 & 83.5 & 82.0 & 84.5 & 82.0 & 84.06 & Enough \\
\hline Mean & & & & & & & & & 83.39 & Enough \\
\hline
\end{tabular}

Table 4 showed the results of LIP validated by experts and practitioners for Guli Game. The learning objective formulation aspect was acquired the average 84.06 with enough category. The learning material aspect was acquired the average 81.88 with enough category. The learning activity was acquired the average 82.75 with enough category. The learning source was acquired the average 84.19 with enough category. The assessment instrument was acquired the average 84.06 with enough category. All validation aspects that have assessed by experts and practitioners can be concluded that the Guli Game combined the mathematics materials was valid and appropriate used in the teaching and learning processes with some revision.

Table 5

Results of the LIP validated for congkak game

\begin{tabular}{|c|c|c|c|c|c|c|c|c|c|c|}
\hline \multirow[t]{2}{*}{ The Validated Aspect } & \multicolumn{4}{|c|}{$\begin{array}{l}\text { Expert Assessment of } \\
\text { LIP for } 4 \text { Meeting }(\%)\end{array}$} & \multicolumn{4}{|c|}{$\begin{array}{l}\text { Practitioners Assessment } \\
\text { of LIP for } 4 \text { Meeting }(\%)\end{array}$} & \multirow{2}{*}{$\begin{array}{c}\text { Mean } \\
(\%)\end{array}$} & \multirow[t]{2}{*}{ Criteria } \\
\hline & 1 & 2 & 3 & 4 & $\overline{1}$ & 2 & 3 & 4 & & \\
\hline $\begin{array}{l}\text { Learning Objective } \\
\text { Formulation }\end{array}$ & 35.5 & 34 & 1 & 37.5 & 0 & 35.5 & 4.5 & 3.5 & 88.9 & High \\
\hline Learning Material & 32.5 & 30.5 & 32.5 & 79 & 78 & 37.5 & 34.5 & 35 & 83.7 & Enough \\
\hline Learning activity & 74 & 33.5 & 31.5 & 31 & 79 & 33 & 37.5 & 36.5 & 82.0 & Enough \\
\hline Learning source & 34 & 12 & 36 & 31.5 & 75.5 & 2 & 35 & 37 & 85.4 & High \\
\hline Assessment Instrument & 76 & 37 & 33.5 & 35 & 73.5 & 33 & 33.5 & 34.5 & 82.0 & Enough \\
\hline Mean & & & & & & & & & 84.4 & Enough \\
\hline
\end{tabular}

Table 5 showed the results of LIP validated by experts and practitioners for Congkak Game. The learning objective formulation aspect was acquired the average 88.9 with high category. The learning material aspect was acquired the average 83.7 with enough category. The learning activity was acquired the average 82.0 with enough category. The learning source was acquired the average 85.4 with high category. The assessment instrument was acquired the average 82.0 with enough category. Five of validation aspects that have assessed by experts and practitioners was acquired the average 84.4 with enough category. The results validation have showed the Guli Game has used in 
learning process and can be combined with Mathematics materials at Elementary Schools.

\section{Validation of SAS}

After LIP validated by experts and practitioners with some revised, next step is validation SAS because SAS is important thing must be validated by experts and practitioners. The five aspects will be assessed by expert and practitioner namely; content, didactic, construct, technique, and time. The results of experts and practitioners validation can be seen in table below.

Table 6

Results of the SAS validated for statak game

\begin{tabular}{|c|c|c|c|c|c|c|c|c|c|c|}
\hline \multirow{2}{*}{$\begin{array}{l}\text { The Validated } \\
\text { Aspect }\end{array}$} & \multicolumn{4}{|c|}{$\begin{array}{l}\text { Expert Assessment of SAS for } \\
4 \text { Meeting }(\%)\end{array}$} & \multicolumn{4}{|c|}{$\begin{array}{l}\text { Practitioners Assessment of } \\
\text { SAS for } 4 \text { Meeting }(\%)\end{array}$} & \multirow{2}{*}{$\begin{array}{l}\text { Average } \\
(\%)\end{array}$} & \multirow[t]{2}{*}{ Criteria } \\
\hline & 1 & 2 & 3 & 4 & 1 & 2 & 3 & 4 & & \\
\hline Content & 77.5 & 79.5 & 88.5 & 87.0 & 77.4 & 78.6 & 78.6 & 78.6 & 80.7 & Enough \\
\hline Didactic & 82.0 & 81.5 & 71.0 & 84.5 & 68.7 & 66.7 & 66.7 & 66.7 & 73.5 & Enough \\
\hline Construct & 84.0 & 80.0 & 80.5 & 90.5 & 70.0 & 66.7 & 66.7 & 66.7 & 75.6 & Enough \\
\hline Technique & 74.0 & 83.0 & 77.5 & 78.0 & 76.7 & 76.7 & 76.7 & 76.7 & 77.4 & Enough \\
\hline Time & 81.0 & 87.0 & 80.5 & 74.0 & 75.0 & 75.0 & 75.0 & 75.0 & 77.8 & Enough \\
\hline
\end{tabular}

Table 6 was showed the result of experts and practitioners validation. The content aspect was acquired the average 73.5 with enough category. The didactic aspect was acquired the average 75.6 with enough category. The construct aspect was acquired the average 77.4 with enough category. The technique aspect was acquired the average 80.7 with enough category. The time aspect was acquired the average 77.8 with enough category. Five SAS aspect assessed with enough category by expert and practitioner at Statak Game. These results showed that Statak Game can be combined with Mathematics material with some revision.

Table 7

Results of the SAS validated for galah panjang game

\begin{tabular}{|c|c|c|c|c|c|c|c|c|c|c|}
\hline \multirow{2}{*}{$\begin{array}{l}\text { The Validated } \\
\text { Aspect }\end{array}$} & \multicolumn{4}{|c|}{$\begin{array}{l}\text { Expert Assessment of SAS for } \\
4 \text { Meeting }(\%)\end{array}$} & \multicolumn{4}{|c|}{$\begin{array}{l}\text { Practitioners Assessment of } \\
\text { SAS for } 4 \text { Meeting }(\%)\end{array}$} & \multirow{2}{*}{$\begin{array}{l}\text { Average } \\
(\%)\end{array}$} & \multirow[t]{2}{*}{ Criteria } \\
\hline & 1 & 2 & 3 & 4 & 1 & 2 & 3 & 4 & & \\
\hline Content & 88.0 & 86.0 & 83.5 & 73.5 & 77.5 & 83.5 & 77.0 & 80.5 & 81.2 & Enough \\
\hline Didactic & 72.0 & 79.0 & 85.5 & 84.5 & 78.0 & 83.5 & 85.0 & 86.0 & 81.7 & Enough \\
\hline Construct & 81.5 & 83.0 & 88.5 & 77.5 & 79.5 & 84.0 & 85.0 & 76.5 & 81.9 & Enough \\
\hline Technique & 78.5 & 84.0 & 86.5 & 90.0 & 81.0 & 79.5 & 84.0 & 77.0 & 82.6 & Enough \\
\hline Time & 86.5 & 81.0 & 83.0 & 82.5 & 81.5 & 85.0 & 80.0 & 87.5 & 83.4 & Enough \\
\hline Mean & & & & & & & & & 82.2 & Enough \\
\hline
\end{tabular}

Table 7 was showed the result of experts and practitioners validation for Galah Panjang Game. The content aspect was acquired the average 81.2 with enough category. The didactic aspect was acquired the average 81.7 with enough category. The construct aspect was acquired the average 81.9 with enough category. The technique aspect was acquired the average 82.6 with enough category. The time aspect was acquired the average 83.4 with enough category. The average of Five aspect of SAS were 82.2 with 
enough category. From these results can be concluded five aspects haveassessed by expert and practitioner at GalahPanajang Game can be used in the teaching and learning process with revision.

Table 8

Results of the SAS validated for guli game

\begin{tabular}{|c|c|c|c|c|c|c|c|c|c|c|}
\hline \multirow{2}{*}{$\begin{array}{l}\text { The Validated } \\
\text { Aspect }\end{array}$} & \multicolumn{4}{|c|}{$\begin{array}{l}\text { Expert Assessment of SAS for } \\
4 \text { Meeting }(\%)\end{array}$} & \multicolumn{4}{|c|}{$\begin{array}{l}\text { Practitioners Assessment of } \\
\text { SAS for } 4 \text { Meeting }(\%)\end{array}$} & \multirow{2}{*}{$\begin{array}{l}\text { Average } \\
(\%)\end{array}$} & \multirow[t]{2}{*}{ Criteria } \\
\hline & 1 & 2 & 3 & 4 & 1 & 2 & 3 & 4 & & \\
\hline Content & 82 & 81.0 & 84.5 & 80.0 & 78.5 & 83.0 & 80.5 & 78.0 & 80.9 & Enough \\
\hline Didactic & 77 & 85.0 & 80.5 & 79.5 & 76.0 & 82.5 & 85.5 & 81.0 & 80.9 & Enough \\
\hline Construct & 85 & 83.5 & 84.5 & 83.5 & 81.0 & 82.0 & 85.0 & 76.5 & 82.6 & Enough \\
\hline Technique & 72 & 85.5 & 87.0 & 86.5 & 75.0 & 83.5 & 85.0 & 82.0 & 82.1 & Enough \\
\hline Time & 82 & 81.0 & 84.5 & 80.0 & 78.5 & 83.0 & 80.5 & 78.0 & 80.9 & Enough \\
\hline Mean & & & & & & & & & 81.5 & Enough \\
\hline
\end{tabular}

Table 8 was showed the result of experts and practitioners validation for Guli Game. The content aspect was acquired the average 80.9 with enough category. The didactic aspect was acquired the average 80.9 with enough category. The construct aspect was acquired the average 82.6 with enough category. The technique aspect was acquired the average 82.1 with enough category. The time aspect was acquired the average 83.4 with enough category. All aspects have assessed experts and practitioners with enough category. These results were showed that five aspects have assessed by expert and practitioner at Guli already valid and can be used in the teaching and learning process in the classroom with revision

Table 9

Results of the SAS Validated for Congkak Game

\begin{tabular}{|c|c|c|c|c|c|c|c|c|c|c|}
\hline \multirow{2}{*}{$\begin{array}{l}\text { The Validated } \\
\text { Aspect }\end{array}$} & \multicolumn{4}{|c|}{$\begin{array}{l}\text { Expert Assessment of SAS for } \\
4 \text { Meeting }(\%)\end{array}$} & \multicolumn{4}{|c|}{$\begin{array}{l}\text { Practitioners Assessment of } \\
\text { SAS for } 4 \text { Meeting }(\%)\end{array}$} & \multirow{2}{*}{$\begin{array}{l}\text { Average } \\
(\%)\end{array}$} & \multirow[t]{2}{*}{ Criteria } \\
\hline & 1 & 2 & 3 & 4 & 1 & 2 & 3 & 4 & & \\
\hline Content & 80 & 83 & 85.5 & 81.5 & 88 & 83 & 86 & 83 & 83.8 & Enough \\
\hline Didactic & 87 & 91.5 & 89 & 82 & 92 & 92.5 & 93.5 & 87 & 89.3 & High \\
\hline Construct & 86 & 84 & 83.5 & 92 & 77 & 80 & 84 & 88 & 84.3 & Enough \\
\hline Technique & 78.5 & 84 & 85.5 & 76.5 & 78 & 85 & 82.5 & 87 & 82.1 & Enough \\
\hline Time & 84.5 & 78.5 & 82.5 & 84.5 & 80.5 & 83 & 83 & 74.5 & 81.4 & Enough \\
\hline Mean & & & & & & & & & 84.1 & Enough \\
\hline
\end{tabular}

Table 9 was showed the result of experts and practitioners validation for Congkak Game. The content aspect was acquired the average 83.8 with enough category. The didactic aspect was acquired the average 89.3 with high category. The construct aspect was acquired the average 84.3 with enough category. The technique aspect was acquired the average 82.1 with enough category. The time aspect was acquired the average 81.4 with enough category. Experts and practitioners have given a assessment with enough category based on the average score so it can be concluded that All aspects already fulfill good standard for a learning device. 


\section{Trial}

Trial was done at State Elementary Schools at Mandau District Riau Province, the teacher assess LIS has developed.The analysis results show LIS has developed getting average $85,71 \%$ with practical category. The teachers said that the educational product has developed by researcher already practical when implemented in the classroom. The next step is give questionnaire to students were studying use SAS, students response analyzed and acquired the average $88.03 \%$ with category very practical. Students said that SAS can be understood easily. The teaching and learning process uses SAS observed by observer consist of teachers and teacher candidate from Mathematics Department based on four meeting. SAS has developed based on the four regional game (Statak, GalahPanjang, Guli, and Congkak) will be implemented, observed and analyzed. The analysis result of teachers and candidate teacher can be seen in Table 11.

Table10

The analysis results of learning implementation observation

\begin{tabular}{lll}
\hline The Meting & $\%$ of Implementation & Practicality Level \\
\hline First Meeting & $92 \%$ & Very Practical \\
\hline Second Meeting & $93 \%$ & Very Practical \\
\hline Third Meeting & $94 \%$ & Very Practical \\
\hline Forth Meething & $93 \%$ & Very Practical \\
\hline Average & $93 \%$ & Very Practical \\
\hline
\end{tabular}

Based on Table 10, it can be concluded that SAS has developed by the researcher already practical and can be used in the teaching and learning processes. This mean, educational product has developed can be used for adding the knowledge, the understanding, and loving on the cultures especially Riau cultures.

\section{DISCUSSION}

LIP validation results obtained an average with enough categories or with a sufficient level of validity. However, if analyzed for each aspect, there are several aspects that have low scores and need to be revised. The validator commented that in general it could be used, but it needed to be revised aspects that were not yet compatible with learning mathematics in elementary schools. SAS validation results showed that, SAS is sufficiently valid and can be used in teaching and learning. But the didactic aspect needs to be revised and adjusted with a validity level is quite valid. This is because the material is not coherent and the language used is unclear. Overall, learning tools such as LIP and SAS have been said to be valid or can be used to maintain culture through teaching and learning in class. The valid education product will be effective tool to improve education quality especially the teaching and learning in the classroom (Rezeki, Andrian, Wahyuni, Nurkholisah, 2019). The educational product that has said valid by experts and practitioners will be best product to transfer the new concept of the teaching and learning process in the classroom because students will not be bored and find the something interesting for learning in the classroom (Risnawati, Andrian, Azmi, Amir, Nurdin, 2019). 
The results of SAS practicality questionnaire analysis show that students feel easy to use SAS. Prastowo (2014) explained that by using SAS students can find structured directions to understand the material provided. With the SAS students will be easy to understand the learning material. The convenience referred to in this aspect also includes the ease of using SAS.Practical media can support learning and increase the learning outcomes (De Freitas \& Griffiths, 2008). Learning media allows students to think how to improve their learning outcomes (Danielsson \& Wiberg, 2006). The implementation of learning media has developed by education expert can improve learning in the classroom and improve students' skills in using the media with certain technologies. The using of new learning media can get the good result because each student will get difference experience and instructional approaches in teaching and learning process (Yaki, Saat, Sathasivam\&Zulnaidi, 2019).

SAS that is developed makes students interested in learning as evidenced the result analysis was very practical. This means that the SAS developed has been able to make students have high motivation to take part in learning. Learning media can overcome different learning of students, motivate students, increase learning interest, and learning outcomes in classroom (Berry \& Staub, 2011). SAS will be something new for students and they want to try SAS so that they fell so happy because this SAS contain interest picture and color and easy to understand (Risnawati, Andrian, Azmi, Amir, \& Nurdin, 2019).

This problem researchers associate with the characteristics of RME according to Treffers (Klein, Beishuizen, \& Treffers, 1998) that one of the characteristics of RME is interactivity where the learning process will be easier if students communicate with each other the results of their work and ideas. In the RME step there are activities comparing and discussing answers in groups and outside groups. Then students must try to communicate the answers with group answers to obtain material understanding. Therefore, students who tend to be quiet in the classroom will certainly have difficulty understanding the learning material so that it will take a long time to work on SAS. Realistic mathematics approach can be defined to explain the events in real life at students, to test students ideas and to take student for making estimations in real-life events (Arseven, 2015). Realistic mathematics is concept properly for developing the learning devices, learning tools, mathematics procedure in real-life (Heuvel-panhuizen \& Drijvers, 2014). The most important why integration mathematics and Malay Folklore used RME because RME proposed the teaching and learning by traditional approach to mathematics instruction (Webb, Kooij, \& Geist, 2011).

\section{CONCLUSION}

Based on the results of data analysis, it can be concluded that mathematics learning tools based on traditional Malay-based Riau traditional games with realistic mathematics education (RME) approach in elementary schools in the form of LIP and SAS have been tested based on their validity and practicality. LIP and SAS can be effective ways to maintain or transfers knowledge about Riau cultures trough the teaching and learning process in the classroom. LIP and SAS that have developed with engaging experts, teachers, students will be the new education product for increasing education quality in 
future so that teachers can be used this product to improve the teaching quality in the classroom.

\section{ACKNOWLEDGEMENT}

First and foremost, we would like to thank to the Ministry of Director of Higher Education who had provided financial assistance to complete this research. Hopefully this research can provide great benefits for the development of education in Indonesia

\section{REFERENCES}

Akbar, S. (2013). Instrumen Perangkat Pembelajaran. Bandung: Rosdakarya.

Akker, J., Bannan, B., Kelly, A. E., Nieveen, N., \& Plomp, T. (2007). An Introduction to Educational Design Research. In T. Plomp \& N. Nieveen (Eds.). the Netherlands: Netzodruk, Enschede.

Akyeampong, K., Lussier, K., Pryor, J., \& Westbrook, J. (2015). International Journal of Educational Development Improving teaching and learning of basic maths and reading in Africa: Does teacher preparation count? International Journal of Educational Development, 33(3), 272-282. https://doi.org/10.1016/j.ijedudev.2012.09.006

Alibali, M. W., Nathan, M. J., \& Nathan, M. J. (2012). Embodiment in Mathematics Teaching and Learning: Evidence From Learners $\hat{a} €^{\mathrm{TM}}$ and Teachers $\hat{a} €^{\mathrm{TM}}$ Gestures Embodiment in Mathematics Teaching and Learning: Evidence From Learners' and Teachers ' Gestures. The Journal of the Learning Sciences, 21(2), 247-286. https://doi.org/10.1080/10508406.2011.611446

Andrian, D., Kartowagiran, B., \& Hadi, S. (2018). The Instrument Development to Evaluate Local Curriculum in Indonesia. International Journal of Instruction, 11(4), 922-934. https://doi.org/10.12973/iji.2016.9115a

Arseven, A. (2015). Mathematical Modelling Approach in Mathematics Education. Universal Journal of Educational Research, 3(12), 973-980. https://doi.org/10.13189/ujer.2015.031204

Artigue, M. (1999). The Teaching and Learning of Mathematics at the University Level, 46(11), 1377-1385.

Athar, G. (2012). Development Of Mathematical Learning With A Realistic Mathematical Education (RME) Approach (pp. 978-979). Yogyakarta: Matematika FMIPA UNY.

Barnes, H. (2005). Thetheory of Realistic Mathematics Education as a theoretical framework for teaching low attainers in mathematics, Pythagoras, 61, 42-57

Bergeson, T. (2000). Teaching and Learning Mathematics. Bellingham: Superintendent of Public Instruction.

Berry, J., \& Staub, N. (2011). Technology, pedagogy and digital production: a case 
study of children learning new media skills. Journal of Scholarship and Practice, 8(1), 24-33. https://doi.org/10.1080/17439880701343352

Borg, W R \& Gall, M. D. (1983). Educational Research Forth Edition. New York: Longman.

BSNP. (2016). Guide to Curriculum Preparation at the Level of Primary and Secondary Education Unit. Jakarta: Kementererian Pendidikan dan Kebudayaan.

Bungsu, P. (2015). Role of Malay Customary Institutions (MCI) Riau in Preserving Regional Culture in Riau Province, JOM FISIP, 2(2), 1-9.

Chang, K,E.,\& Liu, T,C. (2015). The effects of integrating mobile devices with teaching and learning on students' learning performance: A meta-analysis and research synthesis Sung, Computers \& Education, 94, 252-275

Cronbach, L. J., \& Shavelson, R. J. (2004). My Current Thoughts on Coefficient Alpha and Successor Procedures. Educational and Psychological Measurement, 64(3), 391418. https://doi.org/10.1177/0013164404266386

Danielsson, K., \& Wiberg, C. (2006). Participatory design of learning media: Designing educational computer games with and for teenagers. Interactive Technology \& Smart Education, 3(4), 275-291.

Darling-hammond, L., \& Richardson, N. (2009). Research Review / Teacher Learning : What Matters ?, Educational Leadership, 66(5), 46-53.

De Freitas, S., \& Griffiths, M. (2008). The convergence of gaming practices with other media forms: What potential for learning? A review of the literature. Learning, Media and Technology, 33(1), 11-20. https://doi.org/10.1080/17439880701868796

Dubé, A. \& McEwen, R. (2015). Do Gestures Matter? The implications of using touchscreen devices in mathematics instruction, Learning and Instruction, 40, 89-98 http://dx.doi.org/10.1016/j.learninstruc.2015.09.002

Duval, R. (2006). A cognitive analysis of problems of comprehension in a learning of mathematics, Educational Studies in Mathematics, 61, 103-131. https://doi.org/10.1007/s10649-006-0400-z

Efendi, R., Rustaman, N. Y., \& Kaniawati, I. (2018). Development Module Oriented Science Technology Society Indue Science Literacy Assessment for 7th-Grade Junior High School Students in 2nd -Semester Development Module Oriented Science Technology Society Indue Science Literacy Assessment for 7th-Grade Juni. In Materials Science and Engineering (Vol. 335, pp. 1-6). IOP Publishing. https://doi.org/10.1088/1757-899X/335/1/012089

Eğmir, E., Erdem, C., \& Koçyiğit, M. (2017). Trends in Educational Research: A Content Analysis of the Studies Published in International Journal of Instruction. International Journal of Instruction, 10(3), 277-294. https://doi.org/10.12973/iji.2017.10318a 
Freeman, S., Eddy, S. L., Mcdonough, M., Smith, M. K., Okoroafor, N., Jordt, H., \& Pat, M. (2014). Active learning increases student performance in science, engineering, and mathematics, 111(23), 8410-8415. https://doi.org/10.1073/pnas.1319030111.

Gravemeijer, K\&Doorman, M.(1999). Context problems in realistic mathematics education: a calculus course as an example. Educational Studies in Mathematics, 39, 111-129.

Greenhow, C., \& Lewin, C. (2016). Social media and education: reconceptualizing the boundaries of formal and informal learning. Learning, Media and Technology, 41(1), 6 30. https://doi.org/10.1080/17439884.2015.1064954

Gutstein, E., \& Chicago, I. (2003). Teaching and Learning Mathematics for Social Justice in an Urban, Latino School, 34(1), 37-73.

Hadi, S., \& Andrian, D. (2018). 2018. Detecting Teacher Difficulties in Implementing the Local Curriculum Developed by the Local Government. The New Educational Review, 53(3), 250-260.

Heuvel-Panhuizen, M, V\&Drijvers, P. (2014). Realistic Mathematics Education. Encyclopedia of Mathematics Education, 522-534. DOI 10.1007/978-94-007-4978-8.

Heuvel-Panhuizen, M, V, D. (2003). The didactical use of models in realistic mathematics education: an example from a longitudinal trajectory on percentage. Educational Studies in Mathematics, Vol. 54: 9-35

Heuvel-panhuizen, M. Van Den, \& Drijvers, P. (2014). Realistic Mathematics Education. Encyclopedia of Mathematics Education, 522-534. https://doi.org/10.1007/978-94-007-4978-8

Hill, H. C., Ball, D. L., Hill, C., \& Loewenberg, D. (2004). for Teaching: Learning Mathematics Results from California $\hat{a} €^{\mathrm{TM}} \mathrm{s}$ Mathematics Professional Development Institutes, 35(5), 330-351.

Kersting, N., Givvin, K. B., Angeles, L., Stigler, J., \& Angeles, L. (2010). Teachers' Analyses of Classroom Video Predict Student Learning of Mathematics: Further Explorations of a Novel Measure of Teacher Knowledge. Journal of Teacher Education, 61(72), 172-181. https://doi.org/10.1177/0022487109347875

Klein, A. S., Beishuizen, M., \& Treffers, A. (1998). The Empty Number Line in Dutch Second Grades : Realistic Versus Gradual Program Design, 29(4), 443-464.

Kuo-En Chang, Lin-Jung Wu, Shing-Chuang Lai \& Yao-Ting Sung (2014): Using mobile devices to enhance the interactive learning for spatial geometry, Interactive Learning Environments, 1-19, DOI: 10.1080/10494820.2014.948458

Lerman, S. (2014). Cultural, Discursive Psychology: A Sociocultural Approach to Studying the Teaching and Learning of Mathematics, (May 2007). https://doi.org/10.1007/0-306-48085-9

Omar-fauzee, M. S. (2009). The Effectiveness of Imagery and Coping Strategies in 
Sport Performance. European Journal of Social Sciences, 9(1), 97-108. https://doi.org/10.1080/21520704.2010.528173

Prastiwi, Y. (2013). Transmitting Local Cultural Knowledge through English as Foreign Language (EFL) Learning as a Means of Fostering "Unity in Diversity." Academic Journal of Interdisciplinary Studies, 2(3), 507-514. https://doi.org/10.5901/ajis.2013.v2n3p507

Prastowo, A. (2014). Development of Thematic Teaching Materials. Jakarta: Kencana.

Riccomini, P. J., Smith, G. W., Hughes, E. M., \& Fries, K. M. (2015). The Language of Mathematics : The Importance of Teaching and Learning Mathematical Vocabulary, 31, 235-252. https://doi.org/10.1080/10573569.2015.1030995

Risnawati, Andrian, D., Azmi, M. P., Amir, Z., \& Nurdin, E. (2019). Development of a

Definition Maps-Based Plane Geometry Module to Improve the Student Teachers' Mathematical Reasoning Ability. International Journal of Instruction, 12(3), .

Rochmad. (2012). Desain Model Pengembangan Perangkat Pembelajaran Matematika. Jurnal Kreano, 3(1), 59-71.

Rezeki, S., Andrian, D., Wahyuni, A., \& Nurkholisah. (2019). The sustainability concept of Riau cultures through development of mathematics learning devices based on Riau folklore at elementary schools, Journal of Physics: Conference Series, 1-11

Schleppegrell, M. J. (2014). Reading \& Writing Quarterly: Overcoming Learning Difficulties The Linguistic Challenges of Mathematics Teaching and Learning: A Research Review, 23(2), 37-41. https://doi.org/10.1080/10573560601158461

Schoenfeld, A. H. (1992). Learning to Think Mathematically: Sense -Making in Mathematics, 334-370.

Shih, P., Velan, G. M., \& Shulruf, B. (2017). Shared values and socio-cultural norms: Elearning technologies from a social practice perspective. Issues in Educational Research, 27(3), 550-566.

Star, J. R., \& Strickland, Æ. S. K. (2008). Learning to observe : using video to improve preservice mathematics teachers' ability to notice, 11, 107-125. https://doi.org/10.1007/s10857-007-9063-7

Stein, M. K., \& Lane, S. (1996). Educational Research and Evaluation : An International Journal on Theory and Practice Instructional Tasks and the Development of Student Capacity to Think and Reason: An Analysis of the Relationship between Teaching and Learning in a Reform Mathematics P, 1(2), 50-80. https://doi.org/10.1080/1380361960020103

Strouse, S. M., \& Nickerson, C. J. (2016). Professional culture brokers: Nursing faculty perceptions of nursing culture and their role in student formation. Nurse Education in Practice, 18, 10-15. https://doi.org/10.1016/j.nepr.2016.02.008 
Temli Durmuş, Y. (2016). Effective Learning Environment Characteristics as a requirement of Constructivist Curricula: Teachers' Needs and School Principals' Views. International Journal of Instruction, 9(2), 183-198. https://doi.org/10.12973/iji.2016.9213a

Vinner, S. (2015). The Role of Definitions in the Teaching and Learning of Mathematics THE ROLE OF DEFINITIONS, (June). https://doi.org/10.1007/0-30647203-1

Yaki, A.,A., Saat, R.,M, Sathasivam, R.,P\& Zulnaidi, H. (2019). Enhancing science achievement utilising an integrated stem approach,Malaysian Journal of Learning and Instruction: Vol. 16, No. 1, 181-205

Webb, D. C., Kooij, H., \& Geist, M. R. (2011). Design Research in the Netherlands: Introducing Logarithms Using Realistic Mathematics Education. Journal of Mathematics Education at Teachers Colleage, 2, 47-52.

Wood, R., \& Ashfield, J. (2008). The use of the interactive whiteboard for creative teaching and learning in literacy and mathematics: a case study, 39(1), 84-96. https://doi.org/10.1111/j.1467-8535.2007.00703.x

Raut, P \& Patil, V. (2016). Use of Social Media in Education: Positive and Negative impact on the students, International Journal on Recent and Innovation Trends in Computing and Communication, 4(1), 281-285.

Olaore, I., B. (2014). The Impacts (Positive and Negative) of ICT on Education in Nigeria, Development country studies, 4(23), 154-156. 